\title{
Is It Possible to Defend the Moral Permissibility of Abortion without Deciding on the Moral Status of the Human Fetus?
}

\author{
Ana Jimena Casillas Castañeda \\ Universidad Panamericana, Mexico City, Mexico \\ Email: jimenacasillas@gmail.com
}

Received 18 December 2015; accepted 2 January 2016; published 6 January 2016

Copyright (C) 2016 by author and OALib.

This work is licensed under the Creative Commons Attribution International License (CC BY). http://creativecommons.org/licenses/by/4.0/

(c) (i) Open Access

\begin{abstract}
In this article I intend to defend the moral permissibility of abortion through metaphysics, allowing the reader to change or confirm his or her point of view about abortion under the light of reason. To be able to defend the main idea, abortion is something that affects not only a human life but every living being.
\end{abstract}

Keywords

Being, Motion, Aristotle, Metaphysics, De Animae, Movement, Soul, Living Being, Human Life Subject Areas: Sociology

It has been debated about abortion in many ways as a corruption of being, or as wilful act of women as a right to decide what to do with their own bodies, as a way to end overpopulation, etc. matters that the State is trying to conceal. So I decided to search for an argument that doesn't tend to any point, but to explain why the moral permissibility of abortion doesn't depend on the State. It depends on values that cannot be regulated by it, but in nature. First, because we are talking about a living being. Why? Well, the proper definition of a living being we can find it in Aristotle about nature: “is an inner principle of change and being at rest” [1]. Which means, every being that is able to move by itself must be considered a living one. These active powers or potentialities ( $d u$ nameis), are external principles of change and being at rest [2]. So we can say that nature is a cause for efficiency, the cause that gets things done, and that animates things to action [3]. There are different types of motion analysed by Aristotle: motion is the actuality of a potentiality of the entity undergoing motion as a passive potentiality for the change, coming as natural (phusei) or according to nature (kata phusin), or forced (biâi) or contrary to nature (paraphusin). The movement is caused by contraries, in rest or in motion, where nature has the ability to possess both in Physics Bk. 8 [4].

How to cite this paper: Castañeda, A.J.C. (2016) Is It Possible to Defend the Moral Permissibility of Abortion without Deciding on the Moral Status of the Human Fetus? Open Access Library Journal, 3: e2116.

http://dx.doi.org/10.4236/oalib.1102116 
Once established the definition of motion, in De Animae we can find a more proper definition of the different kinds of movement; those are the ones that apply to every living thing: plants, animals and humans; these motions are a characteristic of their soul, or nature. "Movement; for doubtless, not only is it false that the essence of soul is correctly described by those who say that it is what moves (or is capable of moving) itself, but it is an impossibility that movement should be even an attribute of it... there is no necessity that what originates movement should itself be moved. There are two senses in which anything may be moved — either (a) indirectly, owing to something other than itself, or (b) directly, owing to itself. Things are 'indirectly moved' which are moved as being contained in something which is moved, e.g. sailors in a ship, for they are moved in a different sense from that in which the ship is moved; the ship is 'directly moved'; they are 'indirectly moved'; because they are in a moving vessel. This is clear if we consider their limbs; the movement proper to the legs (and so to man) is walking, and in this case the sailors tare not walking... There are four species of movement-locomotion, alteration, diminution, and growth; consequently if the soul is moved, it must be moved with one or several or all of these species of movement. Now if its movement is not incidental, there must be a movement natural to it, and, if so, as all the species enumerated involve place, place must be natural to it... Further, if there be a movement natural to the soul, there must be a counter-movement unnatural to it, and conversely. The same applies to rest as well as to movement; for the terminus ad quem of a thing's natural movement is the place of its natural rest, and similarly the terminus ad quem of its enforced movement is the place of its enforced rest.” [5]

For Aristotle, to have a soul [6] is to be alive, to have movement without being moved by another, but there are different types of living things, for instance: plants, animals and humans, and each of them have specific functions [7].

- Growth, nutrition, (reproduction).

- Locomotion, perception.

- Intellect (thought).

On three corresponding degrees of soul:

- Nutritive soul (plants).

- Sensitive soul (all animals).

- Rational soul (human beings).

So each living being has a specific motion, and also a hierarchy of the complexity of the way they live as regarding their soul, as Aristotle conceived. For instance, plants are a growing for it nutritive soul, also it has been proved that some plants respond to stimuli when we touch them, but they can't move from one place to another by themselves, animals not only have growth but also locomotion and perception to their sensitive soul. Finally, humans not only have growth, locomotion, perception, and intelligence that moves without being moved as an attribute to the rational soul. Every living creature has movement in common, and the only way to realize when something has died is because their lack of movement. Nature indicates its futility by non-moving things, like a rock.

Aristotle analyses each movement on living things, as a specific differentiation between living things. "Living, that is, may mean thinking or perception or local movement and rest, or movement in the sense of nutrition, decay and growth. Hence we think of plants also as living, for they are observed to possess in themselves an originative power through which they increase or decrease in all spatial directions; they grow up and down... and continues to live so long as it can absorb nutriment." [8]

As plants have the movement of growth, and "for it is the only psychic power they possess" [9] the primary movement every living creature has is nourishment to grow, increasing or decreasing within a space. The same analysis is done with animals, for its basic distinction from plants is sensation. "This is the originative power the possession... of sensation that leads us for the first time to speak of living things as animals; for even those beings which possess no power of local movement but do possess the power of sensation we call animals and not merely living things... The primary form of sense is touch, which belongs to all animals... just as the power of self-nutrition can be isolated from touch and sensation generally, so touch can be isolated from all other forms of sense." [10]

But as plants not all animals have all movement, but some more that than others, in case of animals, "some classes of animals have all the senses, some only certain of them (dogs, cats, dolphins, elephants, etc.), others only one (worms, spiders, etc.), the most indispensable, touch.” [11] So the complexity of each kind of movement in animals, draws us nearer to a more perfect kind of animal. There is a hierarchical way of live, from less perfect or mobile to a more complex forms of life. 
I must precise, that the soul is not because of its own entity, but because it is united to a body, a specific matter, not any matter. So humans are because of the unity between body and soul, not any body and not any soul, as reincarnation sets it, or we could have not human babies product of conception, but a dog or an elephant. "Since then the complex here is the living thing, the body cannot be the actuality of the soul; it is the soul which is the actuality of a certain kind of body. Hence the rightness of the view that the soul cannot be without a body, while it cannot be a body; it is not a body but something relative to a body.” [12]

As the moral permissibility of abortion it may not occur, since a living being becomes deprived of movement, all types of movement it has, in the case of a baby: nutrition, sensory, locomotive and thought. Because a being is not living if it lacks a soul or a body, both components come together to form a living creature with the proper movements that proof its quality. As Aristotle states:

"Of the psychic powers above enumerated some kinds of living things, as we have said, possess all, some less than all, others one only. Those we have mentioned are the nutritive, the appetitive, the sensory, the locomotive, and the power of thinking. Plants have none but the first two of them (as Aristotle originally conceived, now we know that plants respond to a certain sense like intensity and duration of light, pests and pathogens), the nutritive and sensory, while another order of living things has this plus the locomotive (the sensory is evident in animals). If any order of living things has the sensory, it must also have the appetitive; for appetite is the genus of which desire, passion, and wish are the species; now all animals have one sense at least, viz. touch, and whatever has a sense has the capacity for pleasure and pain and therefore has pleasant and painful objects present to it, and wherever these are present, there is desire, for desire is just appetition of what is pleasant. Further, all animals have the sense for food (for touch is the sense for food); the food of all living things consists of what is dry, moist, hot, cold, and these are the qualities apprehended by touch; all other sensible qualities are apprehended by touch only indirectly. Sounds, colours, and odours contribute nothing nutrient; flavours fall within the field of tangible qualities. Hunger and thirst are forms of desire, hunger a desire for what is dry and hot, thirst a desire for what is cold and moist; flavour is a sort of seasoning added to both... there is no soul apart from the forms of soul just enumerated.” [13]

So we may think that an embryo or a foetus doesn't seem to move by itself or by another being, but the fact is that it does move independent of the mother. Human beings grow, but the foetus doesn't depend completely on the mother to grow nor does the mother need the foetus to grow, but simultaneously and independently moves because both have a soul. "The soul is the cause or source of the living body. The terms cause and source have many senses. But the soul is the cause of its body alike in all three senses which we explicitly recognize. It is (a) the source or origin of movement, it is (b) the end, it is (c) the essence of the whole living body.” [14] We may not be able to distinguish thought in the embryo, but the other three types of movement are there; we even perceive it inside the womb (kicks, hiccups, etc.); there is a soul with a body there; it may not be a tumour; because the tumour doesn't move by itself, even though it grows. So sense is another quality that a baby inside the womb has: "The senses perceive each other's special objects incidentally; not because the percipient sense is this or that special sense, but because all form a unity: this incidental perception takes place whenever sense is directed at one and the same moment to two disparate qualities in one and the same object, e.g. to the bitterness and the yellowness of bile, the assertion of the identity of both cannot be the act of either of the senses; hence the illusion of sense, e.g. the belief that if a thing is yellow it is bile.” [15]

Another way to prove that the foetus is a human being is because of the necessity of nourishment. "Since nothing except what is alive can be fed, what is fed is the souled body and just because it has soul in it. Hence food is essentially related to what has soul in it. Food has a power which is other than the power to increase the bulk of what is fed by it; so far forth as what has soul in it is a quantum, food may increase its quantity, but it is only so far as what has soul in it is a 'this-somewhat' or substance that food acts as food; in that case it maintains the being of what is fed, and that continues to be what it is so long as the process of nutrition continues... The process of nutrition involves three factors, (a) what is fed, (b) that wherewith it is fed, (c) what does the feeding; of these (c) is the first soul, (a) the body which has that soul in it, (b) the food. But since it is right to call things after the ends they realize, and the end of this soul is to generate another being like that in which it is, the first soul ought to be named the reproductive soul... We can apply this analogy here if we recall that all food must be capable of being digested, and that what produces digestion is warmth; that is why everything that has soul in it possesses warmth.” [16]

Finally, "all natural bodies are organs of the soul. This is true of those that enter into the constitution of plants as well as of those which enter into that of animals. This shows that that the sake of which they are is soul." [17] 
By that any human is a living entity, and by that it cannot be killed or end its living process in any other way that is not by natural causes, "the soul is also the cause of the living body as the original source of local movement... But change of quality and change of quantity are also due to the soul. Sensation is held to be a qualitative alteration, and nothing except what has soul in it is capable of sensation. The same holds of the quantitative changes which constitute growth and decay; nothing grows or decays naturally except what feeds itself, and nothing feeds itself except what has a share of soul in it." [18]

So, if we ask Aristotle about abortion, it is clear that there is no way one can abort, because we are depriving another human life. It would be the same as killing.

\section{References}

[1] As Commented by Aristotle. Physics 2.1, 192b20-23. Translated by R. P. Hardie and R. K. Gaye. http://classics.mit.edu/Aristotle/physics.html

[2] Aristotle. Metaphysics 9.8, 1049b5-10.Translated by W. D. Ross. http://classics.mit.edu/Aristotle/metaphysics.html

[3] As Seen in Aristotle’s Physics 2.7, 198a24-27, and cf. Metaphysics 8.4, 1044a32-b1.

[4] Aristotle Physics 8.4, 255a5-18. Translated by R. P. Hardie and R. K. Gaye. http://classics.mit.edu/Aristotle/physics.html

[5] DA 405b31-406a11 Bodnar, I. (2012) Aristotle’s Natural Philosophy. In: Zalta, E.N., Ed., The Stanford Encyclopedia of Philosophy, Spring Edition. http://plato.stanford.edu/archives/spr2012/entries/aristotle-natphil/ https://faculty.washington.edu/smcohen/320/psyche.htm

[6] What Aristotle Calls the "Substance (Ousia, ov̉oía) and Nature" of the Soul (or Living) Should Explain Its Attributes

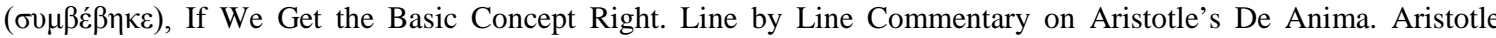
Eugene T. Gendlin, Ph.D. University of Chicago. Published by the Focusing Institute.

[7] DA 413a23 As Seen On the Soul. Aristotle. Translated by J. A. Smith. http://classics.mit.edu//Aristotle/soul.html

[8] DA 413b As Seen On the Soul. Aristotle. Translated by J. A. Smith. http://classics.mit.edu//Aristotle/soul.html

[9] DA 413b15 As Seen On the Soul. Aristotle. Translated by J. A. Smith. http://classics.mit.edu//Aristotle/soul.html

[10] DA 413b20 As Seen On the Soul. Aristotle. Translated by J. A. Smith. http://classics.mit.edu//Aristotle/soul.html

[11] DA413b30 As Seen On the Soul. Aristotle. Translated by J. A. Smith. http://classics.mit.edu//Aristotle/soul.html

[12] DA 414a15 As Seen On the Soul. Aristotle. Translated by J. A. Smith. http://classics.mit.edu//Aristotle/soul.html

[13] DA 414a20-414b20 As Seen On the Soul. Aristotle. Translated by J. A. Smith. http://classics.mit.edu//Aristotle/soul.html

[14] DA 415a10 As Seen On the Soul. Aristotle. Translated by J. A. Smith. http://classics.mit.edu//Aristotle/soul.html

[15] DA 417a As Seen On the Soul. Aristotle. Translated by J. A. Smith. http://classics.mit.edu//Aristotle/soul.html

[16] DA 416a20-416b35 As Seen On the Soul. Aristotle. Translated by J. A. Smith. http://classics.mit.edu//Aristotle/soul.html

[17] DA 415b15 As Seen On the Soul. Aristotle. Translated by J. A. Smith. http://classics.mit.edu//Aristotle/soul.html

[18] DA 415b25 As Seen On the Soul. Aristotle. Translated by J. A. Smith. http://classics.mit.edu//Aristotle/soul.html

[19] https://archive.org/details/aristotledeanima005947mbp 